\title{
Source apportionment and dynamic changes of carbonaceous aerosols during the haze bloom-decay process in China based on radiocarbon and organic molecular tracers
}

\author{
Junwen Liu ${ }^{1}$, Jun $\mathrm{Li}^{1}$, Di Liu ${ }^{1}$, Ping Ding ${ }^{2}$, Chengde Shen ${ }^{2}$, Yangzhi Mo ${ }^{1}$, Xinming Wang ${ }^{1}$, Chunling Luo ${ }^{1}$, \\ Zhineng Cheng ${ }^{1}$, Sönke Szidat ${ }^{3}$, Yanlin Zhang ${ }^{3}$, Yingjun Chen ${ }^{4}$, and Gan Zhang ${ }^{1}$ \\ ${ }^{1}$ State Key Laboratory of Organic Geochemistry, Guangzhou Institute of Geochemistry, Chinese Academy of Sciences, \\ Guangzhou 510640, China \\ ${ }^{2}$ State Key Laboratory of Isotope Geochemistry, Guangzhou Institute of Geochemistry, Chinese Academy of Sciences, \\ Guangzhou 510640, China \\ ${ }^{3}$ Department of Chemistry and Biochemistry \& Oeschger Centre for Climate Change Research, University of Bern, \\ Berne, 3012, Switzerland \\ ${ }^{4}$ College of Environmental Science and Engineering, Tongji University, Shanghai 200092, China
}

Correspondence to: Jun Li (junli@gig.ac.cn)

Received: 13 September 2015 - Published in Atmos. Chem. Phys. Discuss.: 14 December 2015

Revised: 18 February 2016 - Accepted: 23 February 2016 - Published: 8 March 2016

\begin{abstract}
Fine carbonaceous aerosols (CAs) is the key factor influencing the currently filthy air in megacities in China, yet few studies simultaneously focus on the origins of different CAs species using specific and powerful source tracers. Here, we present a detailed source apportionment for various CAs fractions, including organic carbon (OC), water-soluble OC (WSOC), water-insoluble OC (WIOC), elemental carbon (EC) and secondary OC (SOC) in the largest cities of North (Beijing, BJ) and South China (Guangzhou, GZ), using the measurements of radiocarbon and anhydrosugars. Results show that non-fossil fuel sources such as biomass burning and biogenic emission make a significant contribution to the total CAs in Chinese megacities: $56 \pm 4$ in BJ and $46 \pm 5 \%$ in GZ, respectively. The relative contributions of primary fossil carbon from coal and liquid petroleum combustions, primary non-fossil carbon and secondary organic carbon (SOC) to total carbon are 19,28 and 54\% in BJ, and 40, 15 and $46 \%$ in GZ, respectively. Non-fossil fuel sources account for 52 in BJ and $71 \%$ in GZ of SOC, respectively. These results suggest that biomass burning has a greater influence on regional particulate air pollution in North China than in South China. We observed an unabridged haze bloom-decay process in South China, which illustrates that both primary and secondary matter from fossil sources played a key role in the
\end{abstract}

blooming phase of the pollution episode, while haze phase is predominantly driven by fossil-derived secondary organic matter and nitrate.

\section{Introduction}

Particulate matter with an aerodynamic diameter of $<2.5 \mu \mathrm{m}$ $\left(\mathrm{PM}_{2.5}\right)$ is either directly emitted from emission sources (chemical industry, power plant, vehicle, biomass burning, soil dust, etc.) or formed as secondary particles via the conversion of volatile organic compounds (VOCs) and inorganic gases $\left(\mathrm{SO}_{2} / \mathrm{NO}_{x} / \mathrm{NH}_{3}\right)$ to the particulate phase. These tiny particles have been shown to cause numerous environmental, health and climate problems that closely link humans and the global climate system (Brunekreef et al., 2002; Dockery et al., 1993; R.-J. Huang et al., 2014; Wang et al., 2011, 2014). Many countries or regions have set strict standards for the ambient concentration of $\mathrm{PM}_{2.5}$ in an attempt to improve public health and protect air quality. For example, the annual and $24 \mathrm{~h} \mathrm{PM}_{2.5}$ standards are regulated at 35 and $75 \mu \mathrm{g} \mathrm{m}{ }^{-3}$, respectively, in China.

As the world's largest contributor of $\mathrm{PM}_{2.5}$ (Y. Huang et al., 2014), China is currently facing the challenge of severe 
air pollution (i.e., haze episodes) (Chan et al., 2008; Zhang et al., 2012), which has already led to numerous negative impacts on the atmospheric environment and public health. Up to 1.2 million premature deaths in China were directly or indirectly correlated with air pollution in 2010 (Lim et al., 2013). Furthermore, haze events in Chinese urban areas, especially in megacities, have become a common phenomenon that can occur during any season owing to the intensive emissions of pollutants and unfavorable meteorological conditions (He et al., 2014; X.-G. Liu et al., 2013). Better understanding of $\mathrm{PM}_{2.5}$ sources and formation processes, which remain unclear due to the complicated chemical constituents, is urgently needed and would greatly facilitate the development of steps to mitigate the serious haze pollution in China.

Carbonaceous aerosols (CAs) in $\mathrm{PM}_{2.5}$ have been shown to be crucial factors in the haze episodes. In a highly polluted region, $\sim 40 \%$ of $\mathrm{PM}_{2.5}$ can be explained by CAs (Cao et al., 2003), exerting remarkable impacts on the atmospheric visibility (Deng et al., 2008). Traditionally, CAs, of which classification approach is method-dependent, are categorized as organic carbon (OC) and elemental carbon (EC). OC represents the less refractory CAs that contain thousands of organic molecules either emitted by primary emission sources (primary organic carbon, POC) or formed by the conversion process of gas-to-particle (secondary organic carbon, SOC). In addition, OC can also be further classified into water-soluble organic carbon (WSOC) and water-insoluble organic carbon (WIOC). EC is formed only during incomplete combustion processes. TC is the sum of OC and EC. In recent years, source apportionments for these carbon species have yielded useful information in China through radiocarbon $\left({ }^{14} \mathrm{C}\right)$-based top-down studies. At the early period, studies related the ${ }^{14} \mathrm{C}$ of atmospheric CAs were focusing on the TC fraction in China. It was reported that $\sim 30-50 \%$ of $\mathrm{PM}_{2.5}$ TC is contributed from modern sources in Beijing during the year of 2001 (Yang et al., 2005). In Lhasa, a remote city of China, non-fossil sources accounted for $\sim 36$ $70 \%$ of TC (Huang et al., 2010). In a background site of Southeast China, Niu et al. (2013) observed the obvious seasonality of percentages of non-fossil sources in TC: $\sim 45$ in summer and $\sim 95 \%$ in winter, respectively. Nowadays, studies are beginning to focus on the origins of sub-fractions of CAs, i.e., EC and OC in the filthy air of Chinese cities. Chen et al. (2013) first systematically studied the ${ }^{14} \mathrm{C}$ levels of EC, also known as black carbon, in East Asia and found that fossil-fuel combustion contributed $80 \pm 6 \%$ of the EC emitted from China, which is confirmed by the studies of Liu et al. (2014) and Zhang et al. (2015). Using the combined measurements of ${ }^{14} \mathrm{C}$ and stable carbon isotope $\left({ }^{13} \mathrm{C}\right)$, Andersson et al. (2015) further pointed out that the sources of EC covering China are highly region-specific, probably due to the big difference of energy consumption among regions. Concerning OC, Zhang et al. (2015) found that the averaged contribution of fossil sources is $35-58 \%$ in Chi- nese cities with the rest coming from non-fossil sources such as biomass burning and biogenic emissions. Through combining a series of analytical methods with ${ }^{14} \mathrm{C}$, R.-J. Huang et al. (2014) believed that haze enveloping Chinese cities is subject to secondary aerosols, which accounts for 30-77 of $\mathrm{PM}_{2.5}$ and $41-71 \%$ of organic aerosols, respectively. However, most of these studies have emphasized only the ${ }^{14} \mathrm{C}$ levels of one or two carbon species, and our understanding of haze formation remains limited. In this study, ${ }^{14} \mathrm{C}$ levels for the various carbon species (WIOC, WSOC, OC, EC, and TC) are reported simultaneously in two cities located in North and South China, respectively. To further constrain the atmospheric behavior of $\mathrm{PM}_{2.5}$, secondary inorganic ions $\left(\mathrm{SO}_{4}^{2-}\right.$, $\mathrm{NO}_{3}^{-}$and $\left.\mathrm{NH}_{4}^{+}\right)$, primary inorganic ions $\left(\mathrm{K}^{+}, \mathrm{Ca}^{2+}, \mathrm{Mg}^{2+}\right.$, $\mathrm{Cl}^{-}$and $\mathrm{Na}^{+}$) and biomass burning-specific organic tracers (Simoneit et al., 2001) (levoglucosan, Lev; Galactosan, Gal; Mannosan, Mann) were also measured. Finally, a detailed source apportionment of CAs and $\mathrm{PM}_{2.5}$ was achieved in the largest city of North (Beijing) and South China (Guangzhou) using the measurements of ${ }^{14} \mathrm{C}$ and other organic and/or inorganic chemicals, and the source dynamics of individual primary and secondary aerosols during the haze bloom-decay process in Guangzhou basing day-to-day time serials and Beijing basing low-to-high $\mathrm{PM}_{2.5}$ concentrations were investigated as well.

\section{Materials and methods}

\subsection{Field sampling campaign}

Twenty-four-hour $\mathrm{PM}_{2.5}$ samples (9.00 a.m. to 9.00 a.m. the following day) were collected continuously on pre-baked quartz fiber filters $(8 \times 10$ inches, Pall $)$ through a highvolume sampler equipped with a $\mathrm{PM}_{2.5}$ inlet $\left(1 \mathrm{~m}^{-3} \mathrm{~min}^{-1}\right.$, XT Instruments, Shanghai, China) in China's two largest megacities, located in North (Beijing, BJ, $39.9^{\circ} \mathrm{N}, 116.4^{\circ} \mathrm{E}$, $\sim 20$ million inhabitants; 21 samples) and South China (Guangzhou, GZ, $23.1^{\circ} \mathrm{N}, 113.3^{\circ} \mathrm{E}, \sim 10$ million inhabitants; 14 samples) during March and April 2013, respectively (Fig. 1). The meteorological parameters during sampling are shown in Supplement Fig. S1. After sampling, the filters were folded, wrapped in aluminum foil, sealed in airtight plastic bags, and stored in a refrigerator at $-20^{\circ} \mathrm{C}$ until analysis. Three field blanks were collected from both sampling sites.

\subsection{Separation for carbon species}

An area of filter was cut and sandwiched by a filtration unit equipped with a quartz cartridge, and subsequently extracted carefully by $100 \mathrm{~mL}$ ultra-pure water $(18.2 \mathrm{M} \Omega)$. Only $\sim 5 \%$ of carbon in original filter was lost during this water-extraction and thus the resulting bias towards the measurement of WIOC and EC and the source apportionment of $\mathrm{TC}$ in the following text is marginal and can be neglected. 

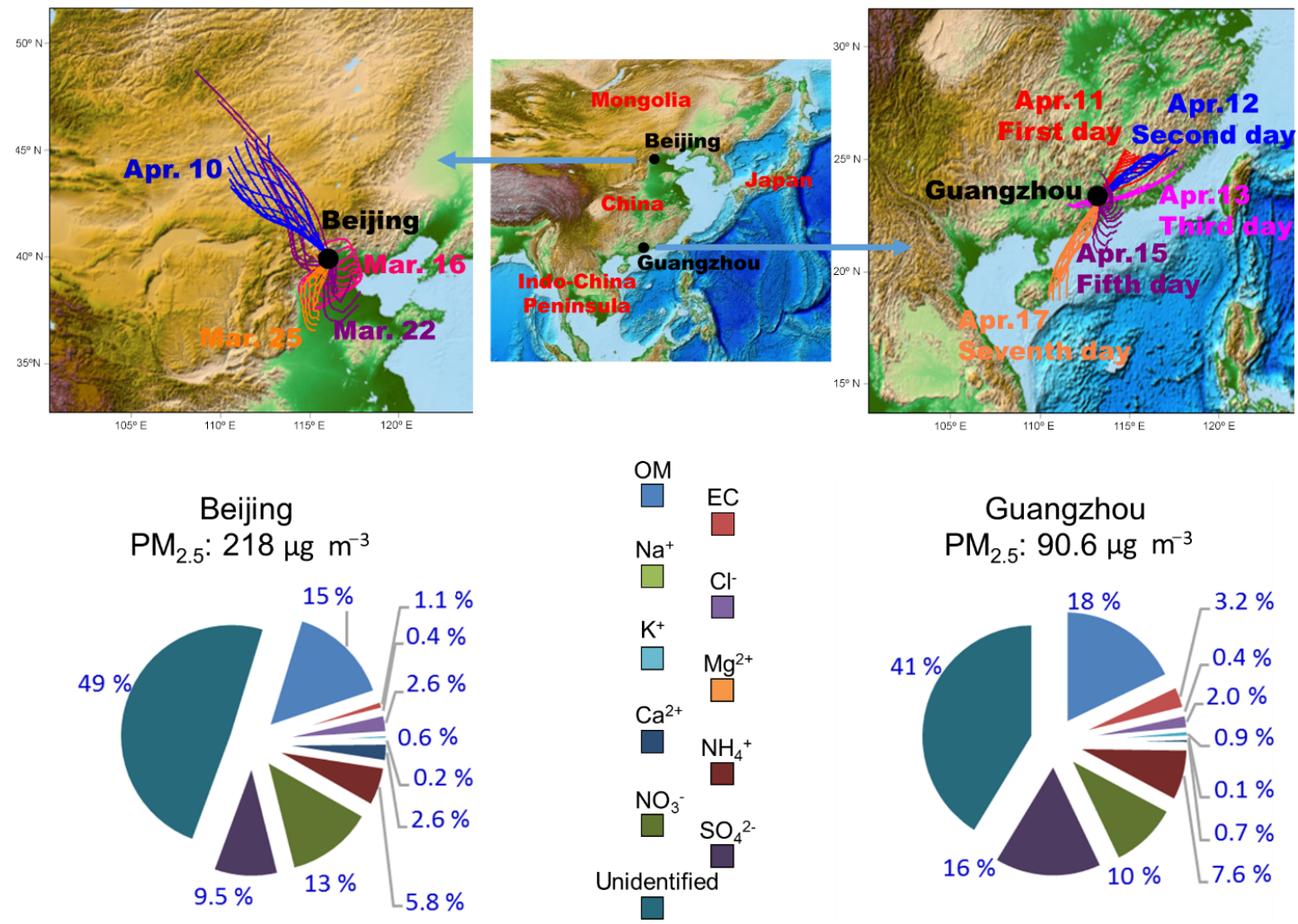

Figure 1. Geographic locations of Beijing and Guangzhou as well as their $\mathrm{PM}_{2.5}$ chemical compositions. Air mass back trajectories within $24 \mathrm{~h}$ (run every $2 \mathrm{~h}$ from the end of sampling) for the selected samples are modeled at $100 \mathrm{~m}$ above ground level by Air Resources Laboratory, National Oceanic and Atmospheric Administration (Hybrid Single Particle Lagrangian Integrated Trajectory Model).

WSOC species were quantified using a TOC analyzer (Shimadzu TOC_VCPH, Japan). The washed filter was dried in a desiccator, wrapped in aluminum foil and stored in a refrigerator. Contribution of carbonate carbon (CC) to fine aerosols generally can be neglected if studies focus on the CAs (Chow and Watson, 2002). While, some early investigations showed that CC-rich dusts derived from deserts may exert a substantial influence on the air quality during the spring season in North China (He et al., 2001; Zheng, et al., 2005). Thus, hydrochloric acid $(1 \mathrm{M})$ was used to remove the potential CC in the samples collected in BJ in this study. WIOC and EC were obtained from the water-filtered sample using an offline carbon analyzer (Sunset Laboratory, Inc., US) by the thermo-optical transmittance method (NIOSH 870). The average WIOC contents in the field blanks from BJ and GZ were $0.25 \pm 0.02$ and $0.26 \pm 0.03 \mu \mathrm{g} \mathrm{cm}^{-2}$, respectively. No $\mathrm{EC}$ and WSOC were detected in any of the field blanks. In this study, the reproducibility of the measurement of WIOC, $\mathrm{EC}$, and WSOC is 5,7 , and $9 \%$, respectively $(n=4)$.

\subsection{Radiocarbon measurements}

Isolation procedures for the ${ }^{14} \mathrm{C}$ measurements of WIOC, $\mathrm{EC}$ and WSOC have been described previously (D. Liu et al.,
2013, 2014; Zhang et al., 2010a). In brief, WIOC and EC were combusted in a stream of pure oxygen at $340^{\circ} \mathrm{C}$ for $15 \mathrm{~min}$ and $65^{\circ} \mathrm{C}$ for $10 \mathrm{~min}$, respectively. Prior to combustion at $65^{\circ} \mathrm{C}$, EC was placed in a tube furnace at $375^{\circ} \mathrm{C}$ for $4 \mathrm{~h}$ with air. WSOC solution was frozen, freeze-dried, and then combusted at $85^{\circ} \mathrm{C}$. Graphite target preparations and accelerator mass spectrometry (AMS) measurements were performed at the Guangzhou Institute of Geochemistry, Chinese Academic Sciences (GIGCAS) and Peking University NEC compact AMS facility, respectively. All ${ }^{14} \mathrm{C}$ values were reported as the fraction of modern carbon $\left(f_{\mathrm{m}}\right)$ after correction with $\delta^{13} \mathrm{C}$ for fractionation. $f_{\mathrm{m}}$ was converted into the fraction of contemporary carbon $\left(f_{\mathrm{c}}\right)$ to eliminate the effect of nuclear bomb tests through conversion factors (Mohn et al., 2008), which were $1.10 \pm 0.05$ for EC and $1.06 \pm 0.05$ for OC in 2013 (Liu et al., 2014), respectively. Both $f_{\mathrm{c}}$ values for TC and $\mathrm{OC}$ were calculated by isotopic mass balance. No blank corrections were performed owing to the low carbon amount in the field blanks in this study, which accounted for only $<2 \%$ of samples. 


\subsection{Levoglucosan, galactosan and mannosan}

Levoglucosan (Lev), Galactosan (Gal) and Mannosan (Mann) are regarded as excellent tracers for biomass burning activities (Simoneit et al., 2001). Detailed analytical procedure has been described in D. Liu et al. (2013, 2014). In brief, a section of filter was removed, spiked with $500 \mathrm{ng}$ of methyl- $\beta$-L-xylanopyranoside (m-XP) as internal standards, extracted with methanol, reduced using a rotary evaporator, filtered through a Teflon syringe filter, dried in a stream of gentle nitrogen, and then reacted with a mixture of $40 \mu \mathrm{L}$ BSTFA (1\% TMCS) and pyridine at $7^{\circ} \mathrm{C}$ for $1 \mathrm{~h}$. Subsequently, this derivatization solution was injected into a gas chromatograph-mass spectrometer (GC-MS, Agilent 78905975 ) with a capillary column (DB-5MS, $30 \mathrm{~m}, 0.25 \mathrm{~mm}$, $0.25 \mu \mathrm{m})$.

\subsection{Inorganic ions}

A $2.54 \mathrm{~cm}^{2}$ filter was punched out, extracted twice in ultrapure water $(18.2 \mathrm{M} \Omega$ ) with a centrifuge, sonicated in an ice-water bath, and filtrated using a Teflon syringe filter $(0.22 \mu \mathrm{m})$. Subsequently, the filtrates were combined and analyzed for anions and ions $\left(\mathrm{Na}^{+}, \mathrm{Cl}^{-}, \mathrm{Ca}^{2+}, \mathrm{Mg}^{2+}\right.$, $\mathrm{K}^{+}, \mathrm{NH}_{4}^{+}, \mathrm{SO}_{4}^{2-}$ and $\mathrm{NO}_{3}^{-}$) using an ion chromatography (Metrohm 883 Basic IC plus, Switzerland). Small amounts of $\mathrm{Mg}^{2+}, \mathrm{Ca}^{2+}, \mathrm{Cl}^{-}$and $\mathrm{SO}_{4}^{2-}$ were detected in the field blanks, and their corresponding concentrations in samples were corrected. The other ions were not detected in the field blank filters. The reproducibility of these ions ranged between 5 and $11 \%(n=4)$ in this study.

\subsection{Methodology for the source apportionment of carbons}

\subsubsection{The separation of fossil and non-fossil carbon species}

The concentrations of non-fossil and/or fossil carbon species were directly calculated using their corresponding $f_{\mathrm{c}}$ values as mentioned above. For example, the concentrations of fossil WIOC $\left(\mathrm{WIOC}_{\mathrm{f}}\right)$ and non-fossil WIOC $\left(\mathrm{WIOC}_{\mathrm{nf}}\right)$ were calculated as follows:

$\mathrm{WIOC}_{\mathrm{f}}=\left(1-f_{\mathrm{c}}(\mathrm{WIOC})\right) \times \mathrm{WIOC}$

$\mathrm{WIOC}_{\mathrm{nf}}=f_{\mathrm{c}}(\mathrm{WIOC}) \times \mathrm{WIOC}$.

Thus, all carbon species could be separated into non-fossil and fossil fractions. EC is formed directly by incomplete combustion processes, with non-fossil source EC emitted from biomass burning activities.

\subsubsection{Primary organic carbon}

OC particles exiting in the present atmosphere are actually a mixture of POC and SOC. POC is the sum of primary biomass burning $\mathrm{OC}\left(\mathrm{POC}_{\mathrm{bb}}\right)$, primary fossil fuel combustion-derived $\mathrm{OC}\left(\mathrm{POC}_{\mathrm{f}}\right)$ and the carbonaceous material that exists in vegetation debris, bioaerosols and resuspended soil organic matter. Since vegetation debris, bioaerosols and soil dust in the air are generally much larger than $2.5 \mu \mathrm{m}$, its portion in $\mathrm{PM}_{2.5}$ is small and can be neglected, especially in highly polluted air. For example, it was reported that vegetation debris accounted for only $\sim 1 \%$ of $\mathrm{PM}_{2.5}$ OC in Beijing, China (Guo et al., 2012). Moreover, although soil dust may contribute to the primary inorganic aerosol at Beijing (R.-J. Huang et al., 2014), its impact on CAs is negligible due to the low carbon content of soil. Thus, this fraction of $\mathrm{OC}$ was ignored in our study. The fraction of $\mathrm{POC}_{\mathrm{bb}}$ can be estimated using the concentration of Lev, which is an excellent molecular marker for biomass burning, with the hypothesis that the $\mathrm{POC}_{\mathrm{bb}}$ / Lev value is maintained at a stable level during transportation from emission sources to the ambient environment. In the real atmosphere, Lev is gradually oxidized and degraded (Hoffmann, et al., 2009). However, this decay occurs mainly in typical summer conditions, with $1 \times 10^{6}$ molecules $\mathrm{cm}^{-3}$ of hydroxyl radicals and independent of relative humidity, according to smog chamber results (Hennigan et al., 2010). Our study, however, was performed in spring with lower temperatures (lower hydroxyl radical levels), and air masses containing biomass burningderived particles were derived mainly from the sub-urban and rural areas around the sampling locations (relatively shorter air transportation distances). Thus, it was appropriate to use Lev to estimate $\mathrm{POC}_{\mathrm{bb}}$ in this study.

$\mathrm{POC}_{\mathrm{bb}}=\mathrm{Lev} \times(\mathrm{POC} / \mathrm{Lev})_{\mathrm{bb}}$

(POC / Lev $)_{\mathrm{bb}}$, the ratio of primary OC to Lev in the pure biomass burning particles, is closely related to the type of biomass burning (Fine et al., 2002). According to information from previously reported emission inventories, the mean

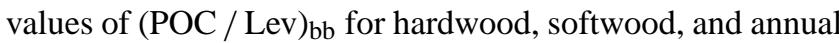
plants are 7.76, 14.2 and 13.5 with uncertainties of 19, 22, and $22 \%$, respectively (Fig. S3).

OC directly emitted from fossil fuel combustion is, in principle, water-insoluble (Weber et al., 2007; Zhang et al., 2014). This was further confirmed in a recent study performed by Dai et al. (2015), who found that $>90 \%$ of traffic tunnel-emitted $\mathrm{OC}$ is water-insoluble, implying that primary fossil organic carbon $\left(\mathrm{POC}_{\mathrm{f}}\right)$ should be nearly exclusively water-insoluble, if considering the limited but existing SOC in the traffic tunnel. Therefore, $\mathrm{POC}_{\mathrm{f}}$ is estimated by the fraction of $\mathrm{WIOC}_{\mathrm{f}}$.

$\mathrm{POC}_{\mathrm{f}}=\mathrm{WIOC} \times\left(1-f_{\mathrm{c}}(\mathrm{WIOC})\right)$

\subsubsection{Secondary organic carbon}

Non-fossil OC is composed of $\mathrm{POC}_{\mathrm{bb}}$ and non-fossil SOC $\left(\mathrm{SOC}_{\mathrm{nf}}\right)$ neglecting any contribution from plant debris. Thus, $\mathrm{SOC}_{\mathrm{nf}}$ can be estimated as follows:

$\mathrm{SOC}_{\mathrm{nf}}=\mathrm{OC}_{\mathrm{nf}}-\mathrm{POC}_{\mathrm{bb}}$ 
Table 1. Data set (average values with standard deviation) for the measured components in this study. Units for the carbon fractions, anhydrosugars and ions are $\mu \mathrm{g} \mathrm{C}, \mathrm{ng}$, and $\mu \mathrm{g} \mathrm{m}^{-3}$, respectively.

\begin{tabular}{|c|c|c|c|c|}
\hline & \multicolumn{2}{|c|}{$\begin{array}{l}\text { Beijing (North China) } \\
\text { (15 Mar-12 Apr 2013) }\end{array}$} & \multicolumn{2}{|c|}{$\begin{array}{l}\text { Guangzhou (South China) } \\
\text { (4-18 Apr 2013) }\end{array}$} \\
\hline & Average & Std. & Average & Std. \\
\hline WIOC & 9.07 & 4.88 & 5.99 & 3.37 \\
\hline WSOC & 10.2 & 5.76 & 4.31 & 2.25 \\
\hline OC & 19.2 & 10.3 & 10.3 & 5.13 \\
\hline $\mathrm{EC}$ & 2.56 & 1.68 & 3.04 & 1.42 \\
\hline $\mathrm{TC}$ & 21.8 & 11.9 & 13.3 & 6.47 \\
\hline Gal & 11.7 & 7.78 & 5.75 & 2.51 \\
\hline Mann & 10.3 & 6.24 & 11.5 & 5.47 \\
\hline Lev & 369 & 249 & 259 & 172 \\
\hline $\mathrm{Na}^{+}$ & 0.83 & 0.32 & 0.34 & 0.15 \\
\hline $\mathrm{NH}_{4}^{+}$ & 13.0 & 10.6 & 7.01 & 3.05 \\
\hline $\mathrm{K}^{+}{ }^{4}$ & 1.43 & 0.90 & 0.82 & 0.34 \\
\hline $\mathrm{Mg}^{2+}$ & 0.48 & 0.19 & 0.07 & 0.03 \\
\hline $\mathrm{Ca}^{2+}$ & 5.63 & 2.54 & 0.60 & 0.36 \\
\hline $\mathrm{Cl}^{-}$ & 5.62 & 3.30 & 1.91 & 1.68 \\
\hline $\mathrm{NO}_{3}^{-}$ & 31.1 & 27.9 & 10.2 & 6.99 \\
\hline $\mathrm{SO}_{4}^{2-}$ & 20.8 & 14.1 & 13.9 & 3.87 \\
\hline
\end{tabular}

WIOC: water-insoluble organic carbon; WSOC: water-soluble organic carbon; OC: organic carbon; EC: elemental carbon; TC: total carbon; Gal: galactosan; Mann: mannosan; Lev: levoglucosan.

It should be noted that the VOC precursors of $\mathrm{SOC}_{\mathrm{nf}}$ can originate from both biogenic emissions and biomass burning.

Studies have found that fossil WSOC can serve as an accurate proxy for fossil SOC (SOC $\mathrm{f}$ ) (Liu et al., 2014; Zhang et al., 2014), which was therefore calculated by the following equation:

$\mathrm{SOC}_{\mathrm{f}}=\mathrm{WSOC} \times\left(1-f_{\mathrm{c}}(\mathrm{WSOC})\right)$.

Some fossil SOC may exist in water-insoluble phase. In Tokyo, Japan, Miyazaki et al. (2006) estimated that $<30 \%$ of SOC is water-insoluble, mainly representing fresh SOC (Favez et al., 2008). It is very likely that practically all SOC species would exist in water-soluble phases, if they underwent sufficient atmospheric reaction. Note that a small part of fresh SOC that exists in the water-insoluble phase is not taken into account for the estimation of fossil SOC, although samples were collected every $24 \mathrm{~h}$ in this study.

\section{Results and discussion}

\section{1 $\mathrm{PM}_{2.5}$ and chemical composition}

Extremely high $\mathrm{PM}_{2.5}$ mass concentrations are detected in both BJ (74.7-418, mean $218 \mu \mathrm{g} \mathrm{m}^{-3}$ ) and GZ (46.1-145, mean $90.6 \mu \mathrm{g} \mathrm{m}^{-3}$ ) (Fig. 1), compared to the Chinese firstgrade air quality standard $\left(35 \mu \mathrm{g} \mathrm{m}^{-3}, 24-\mathrm{h}\right)$ and the World Health Organization $\left(25 \mu \mathrm{g} \mathrm{m}^{-3}\right.$, 24-h). Such elevated $\mathrm{PM}_{2.5}$ loadings can be vividly observed from space (Fig. S2). In this study, the average $\mathrm{PM}_{2.5}$ concentration in $\mathrm{BJ}$ is 2.4 -fold higher than that in GZ, indicating poorer air quality over the North China region, which has been found in previous investigations (Cao et al., 2012) and is also consistent with the fact that BJ and the adjacent suburban and rural areas (North China Plain) have the world's highest population density. Organic matter $(\mathrm{OM})$ is the largest contributor to $\mathrm{PM}_{2.5}$ in both cities (Fig. 1), followed by $\mathrm{NO}_{3}^{-}(13 \%), \mathrm{SO}_{4}^{2-}(9.5 \%), \mathrm{NH}_{4}^{+}$ (5.8\%), $\mathrm{Ca}^{2+}(2.6 \%), \mathrm{Cl}^{-}(2.6 \%)$, and $\mathrm{EC}(1.1 \%)$ in $\mathrm{BJ}$ and $\mathrm{SO}_{4}^{2-}(16 \%), \mathrm{NO}_{3}^{-}(10 \%), \mathrm{NH}_{4}^{+}(7.6 \%), \mathrm{EC}(3.2 \%)$, and $\mathrm{Cl}^{-}(2.0 \%)$ in GZ. OM calculations are based on the relative contributions of WSOC and WIOC in OC, due to the different conversion factors for WIOC to WIOM (1.3) and WSOC to WSOM (2.1) (Yttri et al., 2007; Favez et al., 2009; Sun et al., 2011; Chen et al., 2014). OM is the sum of WIOM and WSOM. The proportions of the other measured chemicals are generally lower than $1 \%$. In this study, $\sim 40-50 \%$ of $\mathrm{PM}_{2.5}$ are unidentified, which is relatively higher than that $(\sim 10-36 \%)$ from a recent study performed in China (R.J. Huang et al., 2014) and probably because we did not measure elementals and their oxidants in $\mathrm{PM}_{2.5}$. Fox example, Chen et al. (2001) found $\sim 35-40 \%$ of $\mathrm{PM}_{2.5}$ cannot be identified in Taiwan without measuring some constituents such as $\mathrm{Cu}, \mathrm{Cd}$, and As. In addition, the water absorbed by organics would also influence the proportion of unidentified fraction in particles (Andrews et al., 2000). Different chemical compositions are largely reflective of their different source characteristics and the corresponding atmospheric processes. For example, the higher concentrations of $\mathrm{Ca}^{2+}$ recorded in $\mathrm{BJ}$ in this study are due to the extensive dust storms originating from deserts in northwestern regions that strongly impact North China in spring (He et al., 2001; Zheng et al., 2005). Road and construction fugitive dust also can lead to a relative higher $\mathrm{Ca}^{2+}$ in $\mathrm{PM}_{2.5}$, while this source may mainly influences Beijing in summer and is insignificant in spring (Zheng et al., 2005). In addition, biomass burning activities, using domestic biofuel, are generally more widespread in North China (Liu et al., 2007), which is reflected by the higher levels of biomass burning markers $\left(\mathrm{Lev}\right.$ and $\left.\mathrm{K}^{+}\right)$in BJ (Table 1).

\subsection{Radiocarbon results}

Although the chemical compositions of $\mathrm{PM}_{2.5}$ can largely be identified by state-of-the-art analytical technology (R.J. Huang et al., 2014), there is not a robust method of performing direct and precise $\mathrm{PM}_{2.5}$ source apportionment exists due to the complexity of the emission sources and atmospheric processes. Carbonaceous aerosols are not only the most important fractions of $\mathrm{PM}_{2.5}$, but also the main factors that significantly lead to severe air pollution and deterioration in atmospheric visibility (Cao et al., 2003, 2007; Deng et al., 2008; Yang et al., 2011) owing to their strong ability for scattering and absorbing visible light (Bond et al., 
2006; Kanakidou et al., 2005). Source apportionment based on ${ }^{14} \mathrm{C}$ analysis has the potential to unambiguously separate the various carbon species into fossil $\left({ }^{14} \mathrm{C}\right.$-free $)$ and nonfossil fractions (modern ${ }^{14} \mathrm{C}$ level) (Gustafsson et al., 2009; R.-J. Huang et al., 2014; Kirillova et al., 2013; D. Liu et al., 2013; Szidat et al., 2004; Weber et al., 2007; Wozniak et al., 2012; Lewis et al., 2004), providing significant information on the $\mathrm{PM}_{2.5}$ sources and corresponding atmospheric processes that they have undergone. Our results show that non-fossil emissions represent a significant portion of the TC in both North and South China: $56 \pm 4$ in BJ and $46 \pm 5 \%$ in GZ, respectively (Table 2). Similar to previous studies conducted in cities around the world (Andersson et al., 2015; Bernardoni et al., 2013; D. Liu et al., 2013; Szidat et al., 2009), EC is derived mainly from fossil-fuel combustion in urban regions. In the remote areas, biomass burning plays a more central role in EC loading. Fox example, $\sim 50-70 \%$ of EC were found coming from the burning of biomass materials in the Arctic (Barrett et al., 2015) and the nature protection area of China (Zhang et al. 2014). On average, a larger proportion of biomass burning in the EC in BJ $(33 \pm 7 \%)$ relative to $\mathrm{GZ}(20 \pm 5 \%)$ indicates that the emissions of biomass burning, e.g., biofuel burning and outdoor fires in North China, are higher than those in South China. This result is consistent with the other observations in this study: the mean concentrations of Lev and $\mathrm{K}^{+}$in $\mathrm{BJ}$ are higher than in GZ by factors of 1.4 and 1.7, respectively (Table 1). More than half of the OC fraction is contributed by non-fossil sources in both BJ (59 $\pm 4 \%)$ and GZ (54 $\pm 6 \%)$. Although the ${ }^{14} \mathrm{C}$ levels in the $\mathrm{OC}$ in $\mathrm{BJ}$ and GZ have similar ranges, the cities differ considerably in the species of WIOC and WSOC. On average, the percentage of non-fossil carbon in WIOC in BJ $(74 \pm 8 \%)$ is $23 \%$ higher than that in GZ $(51 \pm 2 \%)$. This result is probably explained by the large difference between North and South China in the types of biomass burned. In Beijing and its adjacent regions, annual plants, e.g., crop residues and agricultural grass, are the main materials involved in biomass burning activities (Cheng et al., 2013; Duan et al., 2004; Li et al., 2008, 2010; Yan et al., 2006). Whereas $2000 \mathrm{~km}$ south from $\mathrm{BJ}$, in GZ, the types of biomass are marked by hardwood (Liu et al., 2014), which is further confirmed by the compositions of anhydrosugars in this study (Fig. S3). Compared to the hardwood burning (WIOC / OC $=79 \%$ ), OC aerosols emitted directly from combustion of annual plants appeared to be more enriched in WIOC species (WIOC / OC $=97 \%$ ) (Iinuma et al., 2007), which is probably the most important factor in the markedly higher ${ }^{14} \mathrm{C}$ levels in WIOC in BJ compared to those in GZ. In contrast, WSOC in BJ is more depleted in ${ }^{14} \mathrm{C}$ than that in GZ: $46 \pm 13 \%$ of WSOC in BJ and $60 \pm 11 \%$ in GZ is directly correlated with non-fossil sources. WSOC is regarded as a mixture of mainly SOC and POC $_{\mathrm{bb}}$ (Ding et al., 2008; Weber et al., 2007). Such a difference in the WSOC- ${ }^{14} \mathrm{C}$ levels between the two cities could be attributed mainly to the origins and formation processes of the SOC, of which will be discussed below.

\subsection{Source apportionment}

A source apportionment model for carbonaceous aerosols using the combined measurements of ${ }^{14} \mathrm{C}$ and biomass burning tracers was recently reported (Liu et al., 2014). Detailed information with respect to this model is provided in the Methodology section of the paper. Significantly distinct characteristics between BJ and GZ are observed for the source apportionments of TC (Fig. 3). The largest contributor to TC in $\mathrm{BJ}$ is $\operatorname{SOC}_{\mathrm{nf}}(28 \pm 2 \%)$, followed by $\mathrm{SOC}_{\mathrm{f}}(26 \pm 5 \%), \mathrm{POC}_{\mathrm{bb}}(24 \pm 1 \%), \mathrm{POC}_{\mathrm{f}}(10 \pm 4 \%), \mathrm{EC}_{\mathrm{f}}$ $(8 \pm 2 \%)$, and $\mathrm{EC}_{\mathrm{bb}}(4 \pm 1 \%)$, whereas in $\mathrm{GZ}$, an order of $\operatorname{SOC}_{\mathrm{nf}}(31 \pm 2 \%)>\mathrm{POC}_{\mathrm{f}}(22 \pm 4 \%)>\mathrm{EC}_{\mathrm{f}}(18 \pm 3 \%)$ $>\operatorname{SOC}_{\mathrm{f}}(15 \pm 9 \%)>\mathrm{POC}_{\mathrm{bb}}(10 \pm 4 \%)>\mathrm{EC}_{\mathrm{bb}}(4 \pm 1 \%)$ is observed. Consequently, the fraction of primary sources, i.e., the sum of POC and EC, was higher in GZ $(54 \pm 9 \%)$ than that in $\mathrm{BJ}(46 \pm 4 \%)$. The variability of the source apportionment results represent the $1 \sigma$ standard deviation of the individual sources during the study. It should be noted that model uncertainties of the contributors mainly depend on correction factors such as (POC / Lev $)_{b b}$ emission ratios of woodburning markers and conversion factors for determination of the fraction of contemporary carbon from ${ }^{14} \mathrm{C}$ analysis. Typical relative model uncertainties were recently estimated by Zhang et al. (2015) using a similar model approach as 20$25 \%$ for $\mathrm{SOC}_{\mathrm{nf}}, \mathrm{SOC}_{\mathrm{f}}, \mathrm{POC}_{\mathrm{bb}}$, and $\mathrm{POC}_{\mathrm{f}}$ as well as $\sim 13 \%$ for $\mathrm{EC}_{\mathrm{f}}$, and $\mathrm{EC}_{\mathrm{bb}}$.

POC and EC aerosols are independent of the conditions of atmospheric gas reactions and thus can directly reflect the characteristics of local emission sources. The total proportions of $\mathrm{EC}_{\mathrm{f}}$ and $\mathrm{POC}_{\mathrm{f}}$ in $\mathrm{GZ}(40 \pm 6 \%)$ are significantly higher than those in $\mathrm{BJ}(19 \pm 5 \%)$, indicating high emissions from fossil fuel combustion in GZ. The ratios of $\mathrm{POC}_{\mathrm{f}}$ to $\mathrm{EC}_{\mathrm{f}}$ are similar in both cities: $1.3 \pm 0.42$ in $\mathrm{BJ}$ and $1.2 \pm 0.26$ in GZ. These fossil fuel-derived POC / EC ratios in ambient air are considerably lower than the ratios directly derived from industrial coal combustion (2.7-6.1) (Zhang et al., 2008) but close to those of traffic exhaust $(0.5-1.3)$ (He et al., 2008; Zhou et al., 2014). The total proportions of $\mathrm{EC}_{\mathrm{bb}}$ and $\mathrm{POC}_{\mathrm{bb}}$ in the TC accounted for $28 \pm 1$ and $15 \pm 5 \%$ in BJ and GZ, respectively, which confirmed the greater impact of biomass burning on regional air pollution in North China.

Of SOC, $52 \pm 5$ and $71 \pm 11 \%$ are derived from non-fossil sources in BJ and GZ, respectively. Using multi-technique integrated methods, R.-J. Huang et al. (2014) found that 3554 and $65-85 \%$ of the SOC were derived from non-fossil sources in BJ and GZ, respectively, which is consistent with our results. These findings underline the importance of the non-fossil contribution to SOC formation in China's megacities. The considerable difference in SOC composition between the two cities might be due to the significant difference in SOC precursors and corresponding atmospheric reaction 
Table 2. Percentages of non-fossil sources in various carbon species (\%).

\begin{tabular}{llrrrrrr}
\hline Location & Sampling data & OC & WIOC & WSOC & EC & TC & SOC \\
\hline Beijing & $16 \mathrm{Mar}$ & $58 \pm 4$ & $67 \pm 3$ & $52 \pm 3$ & $34 \pm 2$ & $55 \pm 4$ & $52 \pm 11$ \\
(BJ, North China) & $22 \mathrm{Mar}$ & $54 \pm 5$ & $83 \pm 4$ & $53 \pm 3$ & $33 \pm 2$ & $60 \pm 5$ & $55 \pm 11$ \\
& $25 \mathrm{Mar}$ & $59 \pm 4$ & $65 \pm 3$ & $52 \pm 2$ & $24 \pm 1$ & $54 \pm 4$ & $58 \pm 13$ \\
& $10 \mathrm{Apr}$ & $54 \pm 4$ & $82 \pm 4$ & $22 \pm 1$ & $43 \pm 2$ & $53 \pm 4$ & $43 \pm 11$ \\
& Average & $59 \pm 4$ & $74 \pm 8$ & $46 \pm 13$ & $33 \pm 7$ & $56 \pm 4$ & $52 \pm 5$ \\
\hline Guangzhou & $11 \mathrm{Apr}$ & $59 \pm 4$ & $52 \pm 2$ & $68 \pm 3$ & $28 \pm 1$ & $52 \pm 4$ & $74 \pm 10$ \\
(GZ, South China) & $12 \mathrm{Apr}$ & $53 \pm 4$ & $50 \pm 2$ & $60 \pm 3$ & $21 \pm 1$ & $46 \pm 4$ & $77 \pm 10$ \\
& $13 \mathrm{Apr}$ & $57 \pm 4$ & $53 \pm 3$ & $63 \pm 3$ & $19 \pm 1$ & $49 \pm 7$ & $75 \pm 8$ \\
& $15 \mathrm{Apr}$ & $42 \pm 3$ & $48 \pm 2$ & $39 \pm 2$ & $18 \pm 1$ & $38 \pm 3$ & $49 \pm 5$ \\
& $17 \mathrm{Apr}$ & $58 \pm 4$ & $50 \pm 2$ & $68 \pm 3$ & $12 \pm 1$ & $45 \pm 4$ & $78 \pm 6$ \\
& Average & $54 \pm 6$ & $51 \pm 2$ & $60 \pm 11$ & $20 \pm 5$ & $46 \pm 5$ & $71 \pm 11$ \\
\hline
\end{tabular}

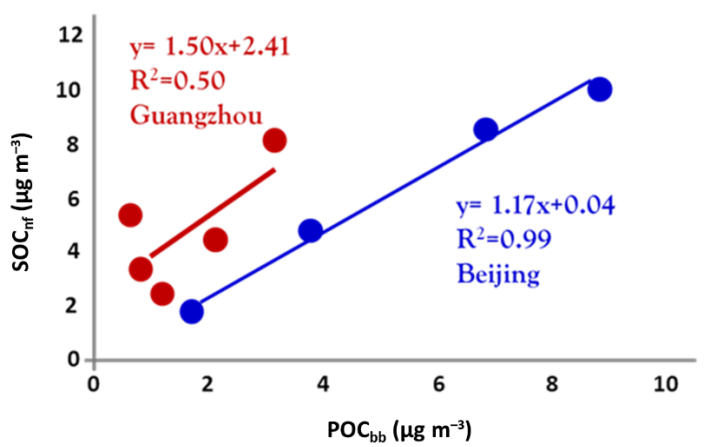

Figure 2. Correlations between the primary biomass burning OC $\left(\mathrm{POC}_{\mathrm{bb}}\right)$ and the non-fossil secondary organic carbon $\left(\mathrm{SOC}_{\mathrm{nf}}\right)$.

processes. In spring (from March to early April), in North China, the land is bare and trees still leafless, whereas, in South China there is lush vegetation, which release non-fossil VOCs (isoprene, $\alpha$-pinene, $\beta$-caryophyllene, etc.), which are SOC precursors. Additionally, a close relationship is observed between $\mathrm{POC}_{\mathrm{bb}}$ and $\mathrm{SOC}_{\mathrm{nf}}$ in $\mathrm{BJ}\left(R^{2}=0.99\right)$ but not in $\mathrm{GZ}\left(R^{2}=0.50\right)$ (Fig. 2), indicating the predominant role of biomass burning-derived VOCs in $\mathrm{SOC}_{\mathrm{nf}}$ formation in North China. Combined with the fact that the total proportion of $\mathrm{EC}_{\mathrm{bb}}$ and $\mathrm{POC}_{\mathrm{bb}}$ in $\mathrm{TC}$ in $\mathrm{BJ}$ is almost twofold higher than that in GZ, efforts to control biomass burning, such as fugitive open fires, burning of agricultural residue, and domestic cooking and heating, are likely the most means of mitigating haze pollution in the North China region. In addition to the difference in the SOC precursors, the difference in meteorological conditions between the two cities is another likely reason for the difference in SOC composition. Compared to fossil-derived SOC, non-fossil SOC would preferentially be formed in a higher humidity environment (Liu et al., 2014; Favez et al., 2008). The relative humidity in GZ (79, 66$95 \%)$ is much higher than that in $\mathrm{BJ}(48,19-79 \%)$ during the sampling campaign.
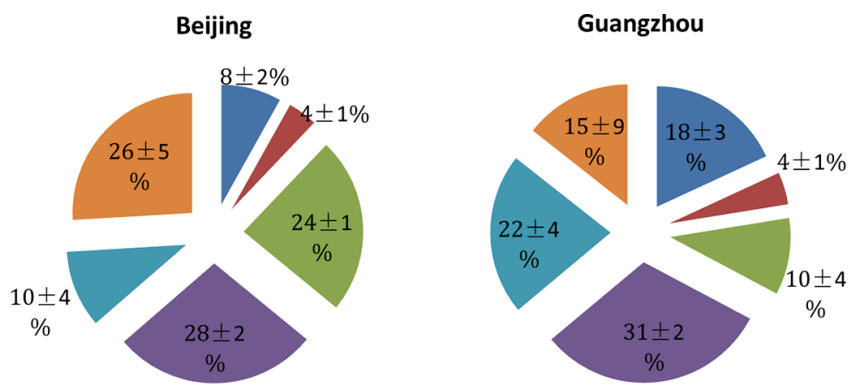

$\square \mathrm{EC}_{\mathrm{f}} \square \mathrm{EC}_{\mathrm{bb}} \square \mathrm{POC}_{\mathrm{bb}} \square \mathrm{SOC}_{\mathrm{nf}} \square \mathrm{POC}_{\mathrm{f}} \square \mathrm{SOC}_{\mathrm{f}}$

Figure 3. Relative contributions (\%) of different carbon species to total carbon with variability of the individual sources during the study. For model uncertainties of the individual fractions see Sect. 3.3.

\subsection{Source dynamics of carbonaceous aerosols during haze process}

Particulate-derived haze pollution is characterized by an elevated $\mathrm{PM}_{2.5}$ mass concentration due to the rapid physical accumulation and intensive atmospheric reactions. Knowledge of the source dynamics of the fine particles is crucial to understanding haze pollution.

An integrated haze process is observed in GZ from 11 to 17 April (Fig. S4). From 11 April $\left(65 \mu \mathrm{g} \mathrm{m}^{-3}\right)$, the $\mathrm{PM}_{2.5}$ concentration increases sharply at an average rate of $34 \mu \mathrm{g} \mathrm{m}^{-3}$ day $^{-1}$ for 2 days, then reaches a plateau from 13 to 15 April (132-145 $\left.\mu \mathrm{g} \mathrm{m}^{-3}\right)$, and fall sharply to $76 \mu \mathrm{g} \mathrm{m}^{-3}$ on 17 April at a rate of $35 \mu \mathrm{g} \mathrm{m}^{-3} \mathrm{day}^{-1}$. To illustrate this haze bloom-decay process, all component concentrations $(C)$ are normalized to the concentration on the first day $\left(C_{\mathrm{o}}\right)$. The concentrations for these components are listed in Supplement Table S1. As shown in Fig. 4c, both total primary and secondary matter concentrations increase by a factor of $\sim 1.5$ from the first day to the second day (blooming stage), indicating that direct emissions and atmospheric reactions 
Guangzhou, South China

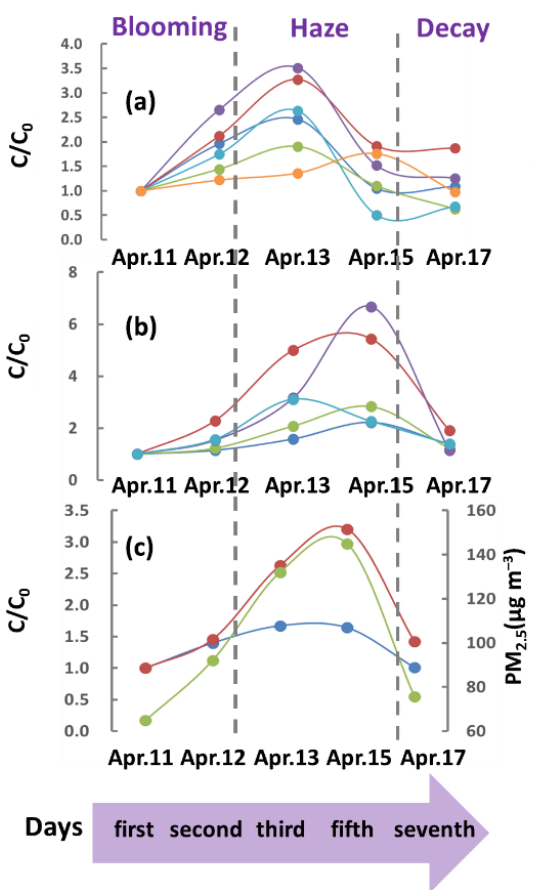

Beijing, North China

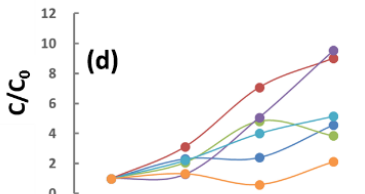

Apr.10 Mar. 22 Mar. 16 Mar. 25

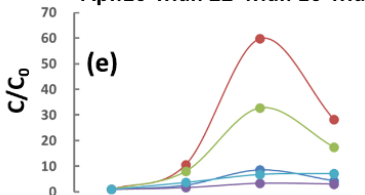

Apr.10 Mar. 22 Mar. 16 Mar. 25

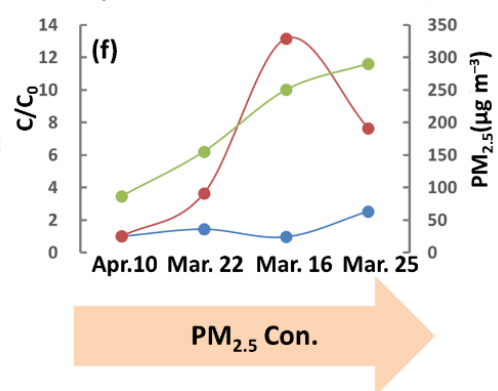

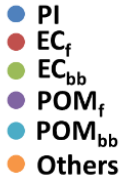

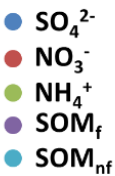

Total primary matter

Total secondary matter

$\mathrm{PM}_{2.5}$

Figure 4. Dynamic changes for the primary and secondary matters in Chinese cities. Detailed concentrations and the calculation methods are shown in Table S2. The first day is 11 April in Guangzhou. For Beijing, samples are ordered by their $\mathrm{PM}_{2.5}$ concentrations. All concentrations $(C)$ are normalized to that of a reference day $\left(C_{\mathrm{O}}\right)$, i.e., the first day and the day with the lowest $\mathrm{PM}_{2.5}$ concentration for Guangzhou and Beijing, respectively. PI: primary ions; $\mathrm{POM}_{\mathrm{f}}$ : primary fossil organic matter; $\mathrm{POM}_{\mathrm{bb}}$ : biomass burning organic matter; $\mathrm{SOM}_{\mathrm{f}}$ : secondary fossil organic matter; $\mathrm{SOM}_{\mathrm{nf}}$ : secondary non-fossil organic matter.

played similar roles in $\mathrm{PM}_{2.5}$ growth during this phase. Notably, primary fossil organic matter $\left(\mathrm{POM}_{\mathrm{f}}\right), \mathrm{EC}_{\mathrm{f}}$ and $\mathrm{NO}_{3}^{-}$ have the highest formation rates, with the values of $C / C_{\mathrm{o}}$ $>2.0$ (Fig. 4a, b), implying greater contribution of vehicle exhaust to the fine particles since $\mathrm{NO}_{3}^{-}$is an indicator of traffic emissions. At the haze outburst (the third day which is also the initial day of haze), the growth rates of total primary and secondary matter diverge significantly, and the $C / C_{\mathrm{o}}$ values are 1.6 and 2.6, respectively, suggesting that atmospheric reactions started to play a more important role in the particle growth than direct emission-derived particles. The growth of $\mathrm{POM}_{\mathrm{f}}, \mathrm{EC}_{\mathrm{f}}$, secondary fossil organic matter $\left(\mathrm{SOM}_{\mathrm{f}}\right)$ and $\mathrm{NO}_{3}^{-}\left(C / C_{\mathrm{o}}>3.0\right)$ are more rapid than that of the other components, again indicating the important role of vehicle emissions. On the last day of the haze episode, all primary matter $C / C_{\mathrm{o}}$ values markedly decrease, with the exception of unidentified materials. This phenomenon could be explained by the rapid shift in the pollutant sources transported by the air masses. As shown in Fig.1, air masses collected at the fifth day originated from southern GZ, a major area of anthropogenic pollutant emission (Zheng et al., 2009) incorporating large-scale industry city districts, such as Foshan, Zhongshan and Dongguan. These industry-derived air masses are likely enriched with those materials that are not identified in this study, such as mineral dust. Furthermore, the $C / C_{\mathrm{o}}$ values for industry-related secondary matter such as $\mathrm{SO}_{4}^{2-}$ (an indicator for industrial emissions) and $\mathrm{SOM}_{\mathrm{f}}$ showed a clear increase on the same day. The reason for the decline in the $C / C_{\mathrm{o}}$ values of $\mathrm{SOM}_{\mathrm{nf}}$ is probably due to the dilution of biogenic and/or biomass burning VOCs with the invasion of these industry-related air masses. All of the $C / C_{\mathrm{o}}$ values of the secondary aerosols decrease markedly on the seventh day (Fig. 4a, b), indicating that the atmospheric reactions has weakened in the post-haze phase, due in part to the scavenging effect of the precipitation that occurred on 16 April on the aged aerosols (Fig. S1).

In $\mathrm{BJ}, \mathrm{PM}_{2.5}$ concentrations remain high during the sampling period, and no clear bloom-decay haze process similar to that observed in GZ is captured. It should be noted, however, that samples for the ${ }^{14} \mathrm{C}$ measurements are not collected on consecutive days in BJ, as is the case for GZ. Therefore, $C / C_{\mathrm{o}}$ values are plotted in Fig. 4 along the increasing trend of $\mathrm{PM}_{2.5}$ concentrations. After comparing the characteristics of relative lower and higher $\mathrm{PM}_{2.5}$ loadings, a recent study revealed that severe haze pollution in North China is controlled by the secondary matters (R.-J. Huang et al., 2014). Our results confirm this conclusion and find an anomalous relationship between $\mathrm{PM}_{2.5}$ level and secondary 
matter (Fig. 4f), pointing out that atmospheric reactivity is not sufficient for the initiation of strong haze events. To a large extent, $\mathrm{PM}_{2.5}$ and secondary aerosols in North China depends on meteorological conditions and the origins of air masses (Guo et al., 2014). $\mathrm{PM}_{2.5}$ pollution on 25 March is more severe than that on 16 March, while the $C / C_{\mathrm{o}}$ of total secondary matter 16 March is much higher than 25 March (Fig. 4f). Most air masses reaching on 16 March come from the most polluted region in North China, i.e., southern BJ (Figs. 1 and S2). These migrated aerosols underwent lots of atmospheric reactions and aging processes. On the other hand, $\mathrm{NO}_{3}^{-}$displays the highest growth rate among all of the types of matter, indicating that traffic emissions contribute most to the air pollution. However, $\mathrm{SOM}_{\mathrm{nf}}$, which in this study is mostly derived from biomass burning (Sect. 3.3), plays a more important role than $\mathrm{SOM}_{\mathrm{f}}$ (Fig. 4e), implying the importance of biomass burning in haze formation in BJ. This is much different from that in South China (Fig. 4b). Furthermore, the $\mathrm{NH}_{4}^{+} C / C_{\mathrm{o}}$ along the increase of $\mathrm{PM}_{2.5}$ loading in $\mathrm{BJ}$ is $\sim 5-10$ times as high as that in GZ. This is probably because North China, especially those regions in southern BJ (Heibei, Henan and Shandong), has the most intensive $\mathrm{NH}_{4}^{+}$emissions from fertilizer and livestock in China (Huang et al., 2012; Zhang et al., 2010b). In addition, it is reported that the emission factor of $\mathrm{NH}_{4}^{+}$from annual plant burning $\left(47 \mathrm{mg} \mathrm{kg}^{-1}\right.$ ) is found to be approximately fivefold that of hardwood burning $\left(10 \mathrm{mg} \mathrm{kg}^{-1}\right)$ (Iinuma et al., 2007). Therefore, the much higher $\mathrm{NH}_{4}^{+}$growth rate in $\mathrm{BJ}$ compared to that of GZ may partly be attributed to the importance of agricultural residue burning in North China.

\section{Conclusions}

Severely high loadings of carbonaceous aerosols (CAs) regarding the deterioration of air quality, risk of human health, and abnormal change of climate system in Chinese megacities has drawn a lot of scientific and public attention. Through the combined measurements of powerful source tracers (radiocarbon and anhydrosugars), this study reveals the significant differences of the origins of various CAs in the megacities of North (Beijing) and South China (Guangzhou). The contribution of non-fossil sources (e.g., domestic heating and cooking) to total carbon (TC), organic carbon (OC), water-soluble OC (WSOC), water-insoluble OC (WIOC), and elemental carbon (EC) is $56 \pm 459 \pm 4,46 \pm 13,74 \pm 8$, and $33 \pm 7 \%$ in Beijing, and $46 \pm 5,54 \pm 6,60 \pm 11,51 \pm 2$, and $20 \pm 5 \%$ in Guangzhou, respectively. Overall, nonfossil sources play a more important role in CAs in North China than in South China. Lower contribution of nonfossil sources to secondary OC in Beijing than Guangzhou is largely because of the much lower humidity and limited biogenic volatile organic compounds in North China during the sampling campaign. The air pollution controls in China probably should be enacted and performed according to the local circumstances. Finally, we find that primary aerosols play an equally important role on the haze blooming phase as secondary aerosols in South China, yet nitrate and fossil secondary organic matter predominate in the haze stage.

\section{The Supplement related to this article is available online at doi:10.5194/acp-16-2985-2016-supplement.}

Acknowledgements. This research was supported by the "Strategic Priority Research Program (B)" of the Chinese Academy of Sciences (Grant no. XDB05040503), the Natural Science Foundation of China (NSFC; no. 41430645 and 41473101), the Guangzhou Science and Technology Plan Projects (no. 201504010002), and the Guangzhou Elites Scholarship Council (JY201332). The authors gratefully acknowledge the NOAA Air Resources Laboratory (ARL) for the provision of the HYSPLIT transport and dispersion mode. We also gratefully acknowledge the MODIS mission scientists and associated NASA personnel for the production of AOD data. This is a contribution (No.IS-2203) of GIGCAS.

Edited by: L. Zhang

\section{References}

Andrews, E., Saxena, P., Musarra, S., Hildemann, L. M., Koutrakis, P., McMurry, P., Olmez, I., and White, W. H.: Concentration and composition of atmospheric aerosols from the 1995 SEAVS experiment and a review of the closure between chemical and gravimetric measurements, J. Air Waste Manage. Assoc., 50, 648664, 2000.

Andersson, A., Deng, J., Du, K., Zheng, M., Yan, C., Sköld, M., and Gustafsson, Ö.: Regionally-varying combustion sources of the January 2013 severe haze events over eastern China, Environ. Sci. Technol., 49, 2038-2043, 2015.

Barrett, T. E., Robinson, E. M., Usenko, S., and Sheesley, R. J.: Source contributions to wintertime elemental and organic carbon in the western arctic based on radiocarbon and tracer apportionment, Environ. Sci. Technol., 49, 11631-11639, 2015.

Bernardoni, V., Calzolai, G., Chiari, M., Fedi, M., Lucarelli, F., Nava, S., Piazzalunga, A., Riccobono, F., Taccetti, F., and Valli, G.: Radiocarbon analysis on organic and elemental carbon in aerosol samples and source apportionment at an urban site in Northern Italy, J. Aerosol Sci., 56, 88-99, 2013.

Bond, T. C. and Bergstrom, R. W., Light absorption by carbonaceous particles: An investigative review, Aerosol Sci. Technol., 40, 27-67, 2006.

Brunekreef, B. and Holgate, S. T.: Air pollution and health, The Lancet, 360, 1233-1242, 2002.

Cao, J., Lee, S., Ho, K., Zhang, X., Zou, S., Fung, K., Chow, J. C., and Watson, J. G.: Characteristics of carbonaceous aerosol in Pearl River Delta Region, China during 2001 winter period, Atmos. Environ., 37, 1451-1460, 2003.

Cao, J., Lee, S., Chow, J. C., Watson, J. G., Ho, K., Zhang, R., Jin, Z., Shen, Z., Chen, G., Kang, Y., Zou, S., Zhang, L., Qi, S., Dai, 
M., Cheng, Y., and Hu, K.: Spatial and seasonal distributions of carbonaceous aerosols over China, J. Geophys. Res.-Atmos., 112, D22S11, doi:10.1029/2006JD008205, 2007.

Cao, J.-J., Shen, Z.-X., Chow, J. C., Watson, J. G., Lee, S.-C., Tie, X.-X., Ho, K.-F., Wang, G.-H., and Han, Y.-M.: Winter and summer PM2.5 chemical compositions in fourteen Chinese cities, J. Air Waste Manage. Assoc., 62, 1214-1226, 2012.

Chan, C. K. and Yao, X.: Air pollution in mega cities in China, Atmos. Environ., 42, 1-42, 2008.

Chen, B., Andersson, A., Lee, M., Kirillova, E. N., Xiao, Q., Kruså, M., Shi, M., Hu, K., Lu, Z., Streets, D. G., Du, K., and Gustafsson, Ö.: Source forensics of black carbon aerosols from China, Environ. Sci. Technol., 47, 9102-9108, 2013.

Chen, J., Qiu, S., Shang, J., Wilfrid, O. M., Liu, X., Tian, H., and Boman, J.: Impact of relative humidity and water soluble constituents of PM2.5 on visibility impairment in Beijing, China, Aerosol Air Qual. Res., 14, 260-268, 2014.

Chen, K. S., Lin, C. F., and Chou, Y. M.: Determination of source contributions to ambient PM2.5 in Kaohsiung, Taiwan, using a receptor model, J. Air Waste Manage. Assoc., 51, 489-498, 2001

Cheng, Y., Engling, G., He, K.-B., Duan, F.-K., Ma, Y.-L., Du, Z.Y., Liu, J.-M., Zheng, M., and Weber, R. J.: Biomass burning contribution to Beijing aerosol, Atmos. Chem. Phys., 13, 77657781, doi:10.5194/acp-13-7765-2013, 2013.

Chow, J. C. and Watson, J. G.: PM2.5 carbonate concentrations at regionally representative Interagency Monitoring of Protected Visual Environments sites, J. Geophys. Res.-Atmos., 107, 8344, doi:10.1029/2001JD000574, 2002.

Dai, S., Bi, X., Chan, L. Y., He, J., Wang, B., Wang, X., Peng, P., Sheng, G., and Fu, J.: Chemical and stable carbon isotopic composition of $\mathrm{PM}_{2.5}$ from on-road vehicle emissions in the PRD region and implications for vehicle emission control policy, Atmos. Chem. Phys., 15, 3097-3108, doi:10.5194/acp-15-30972015, 2015.

Deng, X., Tie, X., Wu, D., Zhou, X., Bi, X., Tan, H., Li, F., and Jiang, C.: Long-term trend of visibility and its characterizations in the Pearl River Delta (PRD) region, China, Atmos. Environ., 42, 1424-1435, 2008.

Ding, X., Zheng, M., Yu, L., Zhang, X., Weber, R. J., Yan, B., Russell, A. G., Edgerton, E. S., and Wang, X.: Spatial and seasonal trends in biogenic secondary organic aerosol tracers and watersoluble organic carbon in the southeastern United States, Environ. Sci. Technol., 42, 5171-5176, 2008.

Dockery, D. W., Pope, C. A., Xu, X., Spengler, J. D., Ware, J. H., Fay, M. E., Ferris Jr., B. G., and Speizer, F. E.: An association between air pollution and mortality in six US cities, New Eng. J. Med., 329, 1753-1759, 1993.

Duan, F., Liu, X., Yu, T., and Cachier, H.: Identification and estimate of biomass burning contribution to the urban aerosol organic carbon concentrations in Beijing, Atmos. Environ., 38, 1275-1282, 2004.

Favez, O., Sciare, J., Cachier, H., Alfaro, S. C., and Abdelwahab, M. M.: Significant formation of water-insoluble secondary organic aerosols in semi-arid urban environment, Geophys. Res. Lett., 35, L15801, doi:10.1029/2008GL034446, 2008.

Favez, O., Cachier, H., Sciare, J., Sarda-Estève, R., and Martinon, L.: Evidence for a significant contribution of wood burn- ing aerosols to $\mathrm{PM}_{2.5}$ during the winter season in Paris, France, Atmos. Environ., 43, 3640-3644, 2009.

Fine, P. M., Cass, G. R., and Simoneit, B. R.: Chemical characterization of fine particle emissions from the fireplace combustion of woods grown in the southern United States, Environ. Sci. Technol., 36, 1442-1451, 2002.

Guo, S., Hu, M., Guo, Q., Zhang, X., Zheng, M., Zheng, J., Chang, C. C., Schauer, J. J., and Zhang, R.: Primary sources and secondary formation of organic aerosols in Beijing, China, Environ. Sci. Technol., 46, 9846-9853, 2012.

Guo, S., Hu, M., Zamora, M., Peng, J., Shang, D., Zheng, J., Du, Z., Wu, Z., Shao, M., Zeng, L., Molina, M. J., and Zhang, R.: Elucidating severe urban haze formation in China, Proc. Natl. Acad. Sci. USA, 111, 17373-17378, 2014.

Gustafsson, Ö., Kruså, M., Zencak, Z., Sheesley, R. J., Granat, L., Engström, E., Praveen, P., Rao, P., Leck, C., and Rodhe, H.: Brown clouds over South Asia: biomass or fossil fuel combustion?, Science, 323, 495-498, 2009.

He, H., Wang, Y., Ma, Q., Ma, J., Chu, B., Ji, D., Tang, G., Liu, C., Zhang, H., and Hao, J.: Mineral dust and $\mathrm{NO}_{x}$ promote the conversion of $\mathrm{SO}_{2}$ to sulfate in heavy pollution days, Scientific Reports, 4, 4172, doi:10.1038/srep04172, 2014.

He, K., Yang, F., Ma, Y., Zhang, Q., Yao, X., Chan, C. K., Cadle, S., Chan, T., and Mulawa, P.: The characteristics of PM2.5 in Beijing, China, Atmos. Environ., 35, 4959-4970, 2001.

He, L.-Y., Hu, M., Zhang, Y.-H., Huang, X.-F., and Yao, T.-T.: Fine particle emissions from on-road vehicles in the Zhujiang Tunnel, China, Environ. Sci. Technol., 42, 4461-4466, 2008.

Hennigan, C. J., Sullivan, A. P., Collett, J. L., and Robinson, A. L.: Levoglucosan stability in biomass burning particles exposed to hydroxyl radicals, Geophys. Res. Lett., 37, L09806, doi:10.1029/2010GL043088, 2010.

Hoffmann, D., Tilgner, A., Iinuma, Y., and Herrmann, H.: Atmospheric stability of levoglucosan: a detailed laboratory and modeling study, Environ. Sci. Technol., 44, 694-699, 2009.

Huang, J., Kang, S., Shen, C., Cong, Z., Liu, K., Wang, W., and Liu, L.: Seasonal variations and sources of ambient fossil and biogenic-derived carbonaceous aerosols based on ${ }^{14} \mathrm{C}$ measurements in Lhasa, Tibet, Atmos. Res., 96, 553-559, 2010.

Huang, X., Song, Y., Li, M., Li, J., Huo, Q, Cai, X., Zhu, T., Hu, M., and Zhang H.: A high-resolution ammonia emission iventory in China, Global Biogeochem. Cy., 26, GB1030, doi:10.1029/2011GB004161, 2012.

Huang, Y., Shen, H., Chen, H., Wang, R., Zhang, Y., Su, S., Chen, Y., Lin, N., Zhuo, S., Zhong, Q., Wang, X., Liu, J., Li, B., Liu, W., and Tao, S.: Quantification of Global Primary Emissions of $\mathrm{PM}_{2.5}, \mathrm{PM}_{10}$, and TSP from Combustion and Industrial Process Sources, Environ. Sci. Technol., 48, 13834-13843, 2014.

Huang, R.-J., Zhang, Y., Bozzetti, C., Ho, K.-F., Cao, J.-J., Han, Y., Daellenbach, K. R., Slowik, J. G., Platt, S. M., Canonaco, F., Zotter, P., Wolf, R., Pieber, S. M., Bruns, E. A., Crippa, M., Ciarelli, G., Piazzalunga, A., Schwikowski, M., Abbaszade, G., SchnelleKreis, J., Ralf, Z., An, Z., Szidat, S., Baltensperger, U., Haddad, I. E., and Prévôt, A. S. H.: High secondary aerosol contribution to particulate pollution during haze events in China, Nature, 514, 218-222, 2014.

Iinuma, Y., Brüggemann, E., Gnauk, T., Müller, K., Andreae, M., Helas, G., Parmar, R., and Herrmann, H.: Source characterization of biomass burning particles: The combustion of selected Eu- 
ropean conifers, African hardwood, savanna grass, and German and Indonesian peat, J. Geophys. Res.-Atmos., 112, D08209, doi:10.1029/2006JD007120, 2007.

Kanakidou, M., Seinfeld, J. H., Pandis, S. N., Barnes, I., Dentener, F. J., Facchini, M. C., Van Dingenen, R., Ervens, B., Nenes, A., Nielsen, C. J., Swietlicki, E., Putaud, J. P., Balkanski, Y., Fuzzi, S., Horth, J., Moortgat, G. K., Winterhalter, R., Myhre, C. E. L., Tsigaridis, K., Vignati, E., Stephanou, E. G., and Wilson, J.: Organic aerosol and global climate modelling: a review, Atmos. Chem. Phys., 5, 1053-1123, doi:10.5194/acp-5-1053-2005, 2005.

Kirillova, E. N., Andersson, A., Sheesley, R. J., Kruså, M., Praveen, P., Budhavant, K., Safai, P., Rao, P., and Gustafsson, Ö.: ${ }^{13}$ Cand ${ }^{14} \mathrm{C}$-based study of sources and atmospheric processing of water-soluble organic carbon (WSOC) in South Asian aerosols, J. Geophys. Res.-Atmos., 118, 614-626, 2013

Lewis, C. W., Klouda, G. A., and Ellenson, W. D.: Radiocarbon measurement of the biogenic contribution to summertime PM2.5 ambient aerosol in Nashville, TN, Atmos. Environ., 38, 60536061, 2004.

Li, L., Wang, Y., Zhang, Q., Li, J., Yang, X., and Jin, J.: Wheat straw burning and its associated impacts on Beijing air quality, Sci. China Ser. D, 51, 403-414, 2008.

Li, W. J., Shao, L. Y., and Buseck, P. R.: Haze types in Beijing and the influence of agricultural biomass burning, Atmos. Chem. Phys., 10, 8119-8130, doi:10.5194/acp-10-8119-2010, 2010.

Lim, S. S., Vos, T., Flaxman, A. D., Danaei, G., Shibuya, K., AdairRohani, H., AlMazroa, M. A., Amann, M., Anderson, H. R., Andrews, K. G., Aryee, M., Atkinson, C., Bacchus, L. J., Bahalim, A. N., Balakrishnan, K., Balmes, J., Barker-Collo, S., Baxter, A., Bell, M. L., and Blore, J. D.: A comparative risk assessment of burden of disease and injury attributable to 67 risk factors and risk factor clusters in 21 regions, 1990-2010: a systematic analysis for the Global Burden of Disease Study 2010, The Lancet, 380, 2224-2260, 2013.

Liu, D., Li, J., Zhang, Y., Xu, Y., Liu, X., Ding, P., Shen, C., Chen, Y., Tian, C., and Zhang, G.: The use of levoglucosan and radiocarbon for source apportionment of $\mathrm{PM}_{2.5}$ carbonaceous aerosols at a background site in East China, Environ. Sci. Technol., 47, 10454-10461, 2013.

Liu, J., Li, J., Zhang, Y., Liu, D., Ding, P., Shen, C., Shen, K., He, Q., Ding, X., Wang, X., Chen, D., Szidat, S., and Zhang, G.: Source Apportionment Using Radiocarbon and Organic Tracers for $\mathrm{PM}_{2.5}$ Carbonaceous Aerosols in Guangzhou, South China: Contrasting Local-and Regional-Scale Haze Events, Environ. Sci. Technol., 48, 12002-12011, 2014.

Liu, S., Tao, S., Liu, W., Liu, Y., Dou, H., Zhao, J., Wang, L., Wang, J., Tian, Z., and Gao, Y., Atmospheric polycyclic aromatic hydrocarbons in North China: a winter-time study, Environ. Sci. Technol., 41, 8256-8261, 2007.

Liu, X. G., Li, J., Qu, Y., Han, T., Hou, L., Gu, J., Chen, C., Yang, Y., Liu, X., Yang, T., Zhang, Y., Tian, H., and Hu, M.: Formation and evolution mechanism of regional haze: a case study in the megacity Beijing, China, Atmos. Chem. Phys., 13, 4501-4514, doi:10.5194/acp-13-4501-2013, 2013.

Miyazaki, Y., Kondo, Y., Takegawa, N. Komazaki, Y., Fukuda, M., Kawamura, K., Mochida, M., Okuzawa, K., and Weber, R. J.: Time-resolved measurements of water-soluble or- ganic carbon in Tokyo, J. Geophys. Res.-Atmos., 111, D23206, doi:10.1029/2006JD007125, 2006

Mohn, J., Szidat, S., Fellner, J., Rechberger, H., Quartier, R., Buchmann, B., and Emmenegger, L.: Determination of biogenic and fossil $\mathrm{CO}_{2}$ emitted by waste incineration based on ${ }^{14} \mathrm{CO}_{2}$ and mass balances, Bioresource Technol., 99, 6471-6479, 2008.

Niu, Z., Wang, S., Chen, J., Zhang, F., Chen, X., He, C., Lin, L., Yin, L., and $\mathrm{Xu}, \mathrm{L}$.: Source contributions to carbonaceous species in $\mathrm{PM}_{2.5}$ and their uncertainty analysis at typical urban, peri-urban and background sites in southeast China, Environ. Pollut., 181, 107-114, 2013.

Simoneit, B. R. and Elias, V. O.: Detecting organic tracers from biomass burning in the atmosphere, Mar. Pollut. Bull., 42, 805810, 2001.

Sun, Y., Zhang, Q., Zheng, M., Ding, X., Edgerton, E. S., and Wang, $X$.: Characterization and source apportionment of water-soluble organic matter in atmospheric fine particles $\left(\mathrm{PM}_{2.5}\right)$ with highresolution aerosol mass spectrometry and GC-MS, Environ. Sci. Technol., 45, 4854-4861, 2011.

Szidat, S., Jenk, T. M., Gäggeler, H. W., Synal, H.-A., Fisseha, R., Baltensperger, U., Kalberer, M., Samburova, V., Reimann, S., Kasper-Giebl, A., and Hajdas, I.: Radiocarbon $\left({ }^{14} \mathrm{C}\right)$-deduced biogenic and anthropogenic contributions to organic carbon (OC) of urban aerosols from Zürich, Switzerland, Atmos. Environ., 38, 4035-4044, 2004

Szidat, S., Ruff, M., Perron, N., Wacker, L., Synal, H.-A., Hallquist, M., Shannigrahi, A. S., Yttri, K. E., Dye, C., and Simpson, D.: Fossil and non-fossil sources of organic carbon (OC) and elemental carbon (EC) in Göteborg, Sweden, Atmos. Chem. Phys., 9, 1521-1535, doi:10.5194/acp-9-1521-2009, 2009.

Wang, Y., Wan, Q., Meng, W., Liao, F., Tan, H., and Zhang, R.: Long-term impacts of aerosols on precipitation and lightning over the Pearl River Delta megacity area in China, Atmos. Chem. Phys., 11, 12421-12436, doi:10.5194/acp-11-12421-2011, 2011.

Wang, Y., Wang, M., Zhang, R., Ghan, S. J., Lin, Y., Hu, J., Pan, B., Levy, M., Jiang, J. H., and Molina, M. J.: Assessing the effects of anthropogenic aerosols on Pacific storm track using a multiscale global climate model, Proc. Natl. Acad. Sci. USA, 111, 68946899, 2014.

Weber, R. J., Sullivan, A. P., Peltier, R. E., Russell, A., Yan, B., Zheng, M., De Gouw, J., Warneke, C., Brock, C., Holloway, J. S., Atlas, E. L., and Edgerton, E.: A study of secondary organic aerosol formation in the anthropogenic-influenced southeastern United States, J. Geophys. Res.-Atmos., 112, D13302, doi:10.1029/2007JD008408, 2007.

Wozniak, A. S., Bauer, J. E., and Dickhut, R. M.: Characteristics of water-soluble organic carbon associated with aerosol particles in the eastern United States, Atmos. Environ., 46, 181-188, 2012.

Yan, X., Ohara, T., and Akimoto, H.: Bottom-up estimate of biomass burning in mainland China, Atmos. Environ., 40, 52625273, 2006.

Yang, F., He, K., Ye, B., Chen, X., Cha, L., Cadle, S. H., Chan, T., and Mulawa, P. A.: One-year record of organic and elemental carbon in fine particles in downtown Beijing and Shanghai, Atmos. Chem. Phys., 5, 1449-1457, doi:10.5194/acp-5-1449-2005, 2005.

Yang, F., Tan, J., Zhao, Q., Du, Z., He, K., Ma, Y., Duan, F., Chen, G., and Zhao, Q.: Characteristics of $\mathrm{PM}_{2.5}$ speciation in repre- 
sentative megacities and across China, Atmos. Chem. Phys., 11, 5207-5219, doi:10.5194/acp-11-5207-2011, 2011.

Yttri, K. E., Aas, W., Bjerke, A., Cape, J. N., Cavalli, F., Ceburnis, D., Dye, C., Emblico, L., Facchini, M. C., Forster, C., Hanssen, J. E., Hansson, H. C., Jennings, S. G., Maenhaut, W., Putaud, J. P., and Tørseth, K.: Elemental and organic carbon in $\mathrm{PM}_{10}$ : a one year measurement campaign within the European Monitoring and Evaluation Programme EMEP, Atmos. Chem. Phys., 7, 5711-5725, doi:10.5194/acp-7-5711-2007, 2007.

Zhang, Q., He, K., and Huo, H.: Policy: cleaning China's air, Nature, 484, 161-162, 2012.

Zhang, Y., Schauer, J. J., Zhang, Y., Zeng, L., Wei, Y., Liu, Y., and Shao, M.: Characteristics of particulate carbon emissions from real-world Chinese coal combustion, Environ. Sci. Technol., 42, 5068-5073, 2008.

Zhang, Y., Liu, D., Shen, C., Ding, P., and Zhang, G.: Development of a preparation system for the radiocarbon analysis of organic carbon in carbonaceous aerosols in China, Nucl. Instr. Methods B, 268, 2831-2834, 2010a.

Zhang, Y., Dore, A. J., Ma, L., Liu, X.J., Ma, W. Q., Cape, J. N., and Zhang, F. S.: Agricultural amomonia emissions inventroy and spatial distribution in the North China Plain, Environ. Pollut., 158, 490-501, 2010b.

Zhang, Y.-L., Li, J., Zhang, G., Zotter, P., Huang, R.-J., Tang, J.H., Wacker, L., Prévôt, A. S., and Szidat, S.: Radiocarbon-based source apportionment of carbonaceous aerosols at a regional background site on Hainan Island, South China, Environ. Sci. Technol., 48, 2651-2659, 2014.
Zhang, Y.-L., Huang, R.-J., El Haddad, I., Ho, K.-F., Cao, J.-J., Han, Y., Zotter, P., Bozzetti, C., Daellenbach, K. R., Canonaco, F., Slowik, J. G., Salazar, G., Schwikowski, M., Schnelle-Kreis, J., Abbaszade, G., Zimmermann, R., Baltensperger, U., Prévôt, A. S. H., and Szidat, S.: Fossil vs. non-fossil sources of fine carbonaceous aerosols in four Chinese cities during the extreme winter haze episode of 2013, Atmos. Chem. Phys., 15, 1299-1312, doi:10.5194/acp-15-1299-2015, 2015.

Zheng, J., Zhang, L., Che, W., Zheng, Z., and Yin, S.: A highly resolved temporal and spatial air pollutant emission inventory for the Pearl River Delta region, China and its uncertainty assessment, Atmos. Environ., 43, 5112-5122, 2009.

Zheng, M., Salmon, L. G., Schauer, J. J., Zeng, L., Kiang, C., Zhang, Y., and Cass, G. R.: Seasonal trends in PM2.5 source contributions in Beijing, China, Atmos. Environ., 39, 3967-3976, 2005.

Zhou, R., Wang, S., Shi, C., Wang, W., Zhao, H., Liu, R., Chen, L., and Zhou, B.: Study on the Traffic Air Pollution inside and outside a Road Tunnel in Shanghai, China, PloS one, 9, e112195, doi:10.1371/journal.pone.0112195, 2014. 